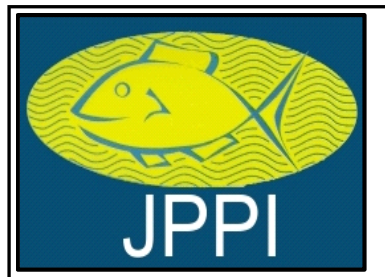

Tersedia online di: http://ejournal-balitbang.kkp.go.id/index.php/jppi
e-mail:jppi.puslitbangkan@gmail.com

JURNAL PENELITIANPERIKANANINDONESIA

Volume 24 Nomor 4 Desember 2018

p-ISSN: 0853-5884

e-ISSN: 2502-6542

Nomor Akreditasi RISTEKDIKTI: 21/E/KPT/2018

\title{
KOMBINASI UKURAN MATA PANCING DAN WARNA UMPAN TIRUAN UNTUK MENINGKATKAN HASIL TANGKAPAN HUHATE
}

\section{COMBINATION OF HOOK SIZE AND ARTIFICIAL BAIT COLORS TO INCREASE CATCH OF POLE AND LINE}

\author{
Fauzan Idris Maspeke ${ }^{\star 1}$, Gondo Puspito ${ }^{2}$ dan lin Solihin ${ }^{2}$ \\ 'Direktorat Jenderal Perikanan Tangkap, JI Medan Merdeka Timur, No. 16 Gedung Mina Bahari II Gambir, Jakarta Pusat, Indonesia \\ ${ }^{2}$ Departemen Pemanfaatan Sumberdaya Perikanan, Institut Pertanian Bogor, Jl. Agatis, Kampus IPB Darmaga Bogor, Indonesia \\ Teregistrasi I tanggal: 31 Juli 2018; Diterima setelah perbaikan tanggal: 31 Januari 2019; \\ Disetujui terbit tanggal: 31 Januari 2019
}

\begin{abstract}
ABSTRAK
Keberhasilan operasi penangkapan ikan dengan huhate sangat tergantung pada beberapa faktor, dua diantaranya adalah ukuran mata pancing dan warna umpan tiruan. Hasil tangkapan huhate berupa cakalang, juvenile tuna, madidihang dan tongkol dapat menjadi optimal bila paduan antara ukuran mata pancing dan warna umpan tiruannya tepat. Oleh karenanya, paduan antara ukuran mata pancing dan warna umpan perlu diujicoba secara bersamaan dalam satu kapal. Tujuan penelitian ini adalah untuk mendapatkan kombinasi ukuran mata pancing dan warna umpan tiruan huhate sehingga menghasilkan jumlah tangkapan terbanyak. Ukuran mata pancing yang digunakan adalah nomor 2 dan 3 . Adapun warna umpan tiruannya merah, biru dan putih. Metode yang digunakan dalam penelitian adalah melalui uji coba penangkapan dengan cara menguji mata pancing yang terdiri atas berbagai kombinasi ukuran dan warna umpan tiruan secara langsung di laut. Kapal huhate yang digunakan untuk operasi penangkapan berukuran 57 GT dengan jumlah pemancing 20 - 30 orang. Hasil uji statistik RALF dan BNT terhadap hasil tangkapan menunjukan bahwa $F_{\text {hit }}$ bernilai 5,214 atau lebih besar daripada $F_{\text {tab }}(3,027)$, atau jumlah hasil tangkapan keenam kombinasi perlakuan berbeda nyata. Kombinasi ukuran mata pancing nomor 3 dan umpan berwarna merah mendapatkan hasil tangkapan sebanyak 2.596 ekor, kemudian diikuti berturut-turut oleh ukuran No.3 dan warna biru sebanyak 2.400 ekor, No. 3 dan warna putih sebanyak 2.109 ekor, No.2 dan warna merah sebanyak 2.106 ekor, No.2 dan warna biru sebanyak 1.333 ekor dan No.2 dan warna putih sebanyak 1.250 ekor.
\end{abstract}

Kata Kunci: Huhate; mata pancing; warna umpan tiruan; hasil tangkapan; uji coba penangkapan

\begin{abstract}
The success of huhate fishing operations is highly dependent on several factors, two of which are the size of hook and the color of the artificial bait. Catch of pole and line consisted of skipjack, juvenile tuna, yellowfin tuna and little tuna will be optimal when the alloy between the hook size and the color of the imitation bait is prorely. Therefore, the combination between the hook size and the color of the bait needs to be tested simultaneously in same fishing vessel. The goal to be achieved in the research is to get a combination of the hook size and artificial bait color are used for catching the largest number of catches. Two type of hook size are used that number 2 and will be combined with three color of artificial bait i.e., red, blue and white. The method used in this research is experimental fishing by using pole and liner sized of 57 GT ship operated by $20-30$ fisherman. The results of RALF and BNT statistical tests on the catch data show that F-hit is 5.214 or greater than F-tab $(3,027)$, that means the number of catches from the six treatment combinations is significantly different. The combination of the hook size number 3 and the red bait color caught 2,596 fishes. The following sequence are 2,400 fishes (No. 3 and blue), 2,109 fishes (No.3 and white), 2,106 fishes (No.2 and red), 1,333 fishes (No.2 and blue) and 1,250 fishes (No.2 and white).
\end{abstract}

Keywords: pole and line; hook size; artificial bait color; experimental fishing 


\section{PENDAHULUAN}

Huhate atau pole and line merupakan salah satu jenis alat penangkapan ikan banyak digunakan oleh nelayan di Sulawesi Utara. Target utama penangkapan adalah jenis-jenis ikan pelagis besar seperti: cakalang, madidihang, tuna mata besar dan tongkol. Kelebihan huhate dibandingkan dengan jenis alat penangkapan ikan lainnya adalah pengoperasiannya mudah dan hasil tangkapan berkualitas tinggi karena menangkap ikan dalam kondisi masih hidup (Susanto et al., 2012). Pengoperasian huhate menjadi lebih efektif dengan semakin maraknya penggunaan rumpon sebagai alat bantu pengumpul ikan. Nelayan tidak perlu lagi mencari daerah penangkapan ikan yang jauh, karena posisi gerombolan ikan sudah diketahui berada di sekitar rumpon (Monintja, 1993).

Keunikan huhate terdapat pada bentuk mata pancingnya yang tidak memiliki pengait dan penggunaan umpan tiruan serta memerlukan umpan ikan hidup dalam proses pengoperasiannya. Fungsi mata pancing hanya sebagai pengait ikan dari laut sebelum ditarik ke atas kapal. Ikan yang terkait pada mata pancing akan segera terlepas ketika dilontarkan ke atas geladak kapal. Terdapat 4 (empat) ukuran mata pancing huhate yang dijual di pasaran, yaitu nomor 1, 2, 3 dan 4. Dari keempatnya, nelayan umumnya menggunakan dua ukuran mata pancing, yaitu nomor 2 dan 3, biasanya dinamakan mata pancing berukuran sedang. Keunikan lainnya adalah penggunaan umpan tiruan dengan berbagai warna dengan tujuan untuk mengelabui ikan target. Warna umpan tiruan yang biasa dipakai oleh nelayan huhate, adalah merah, hijau dan perak (Puspito, 2010). Umpan tiruan berwarna merah didasarkan atas warna tubuh ikan rambe, warna biru menyerupai ikan layang, selar, lolosi dan sardine, sedangkan warna putih mirip dengan warna ikan teri. Kelimanya merupakan makanan ikan-ikan pelagis besar, cakalang, madidihang, tuna mata besar dan tongkol yang mana jenis-jenis ikan umpan tersebut digunakan sebagai umpan ikan hidup (live bait).

Keberhasilan operasi penangkapan ikan menggunakan huhate sangat tergantung pada banyak faktor,dua diantaranya adalah ukuran mata pancing dan warna umpan tiruan yang digunakan. Nelayan biasanya mengkombinasikan antara ukuran mata pancing dan warna umpan tiruan secara acak tanpa melalui kajian ilmiah. Berdasarkan hasil wawancara dengan nelayan huhate, paduan ukuran mata pancing dan warna umpan tiruan yang menghasilkan jumlah tangkapan terbanyak berbeda-beda untuk setiap nelayan. Dengan demikian, kombinasi yang tepat antara ukuran mata pancing dengan warna umpan tiruan harus ditemukan agar jumlah hasil tangkapan huhate menjadi lebih banyak.

Penelitian terkait dengan pengaruh kombinasi antara mata pancing dan warna umpan tiruan terhadap hasil tangkapan sudah pernah dilakukan sebelumnya. Puspito (2010) menggunakan umpan tiruan berwarna merah, hijau dan perak, sedangkan Susanto et al (2012) memakai warna merah dan hijau. Kemudian, Niam et al. (2013) juga meneliti pengaruh warna merah, hijau, biru, dan putih terhadap hasil tangkapan. Selanjutnya Siswoko, et al. (2013) melakukan penelitian jenis/ukuran mata pancing untuk huhate.

Penelitian ini mencoba mengkombinasikan ukuran mata pancing nomor 2 dan 3 dengan umpan tiruan berwarna merah, biru dan putih. Setiap kombinasi ukuran mata pancing dan warna umpan dioperasikan secara bersamaan dengan satu kapal huhate. Hasil yang diharapkan adalah diperoleh kombinasi ukuran mata pancing dan warna umpan tiruan yang tepat untuk mendapatkan jumlah tangkapan ikan terbanyak. Indikator keberhasilannya ditentukan berdasarkan jumlah hasil tangkapan ikan yang diperoleh.

\section{BAHAN DAN METODE Pengumpulan Data}

Penelitian dilakukan melalui percobaan operasi penangkapan ikan dengan huhate menggunakan kapal motor berukuran 57 GT. Lokasi penangkapannya berada di perairan Laut Sulawesi, Laut Halmahera dan di sekitar Teluk Tomini (Gambar 1).

Operasi penangkapan dilakukan sebanyak 18 trip yang berlangsung pada periode Agustus - November 2015. Jumlah hari operasi per trip berkisar antara 4-5 hari. Operasi penangkapan dilakukan pagi hari antara pukul 05.15-09.00 WITA, siang hari (10.00-13.15 WITA) dan sore hari (14.15-16.30 WITA).

Mata pancing huhate yang digunakan bernomor 2 dan 3. Ukuran nomor 3 lebih kecil dibandingkan dengan nomor 2. Gambar 2 menunjukkan bagian-bagian mata pancing huhate dan dimensinya. Adapun warna umpan tiruan yang dipakai adalah merah, biru dan putih. Bahan umpan tiruan berupa bulu ayam dan tali rafia. Kombinasi ukuran mata pancing dan warna umpan berjumlah 6 kombinasi dan dijadikan sebagai perlakuan (Tabel 1). 


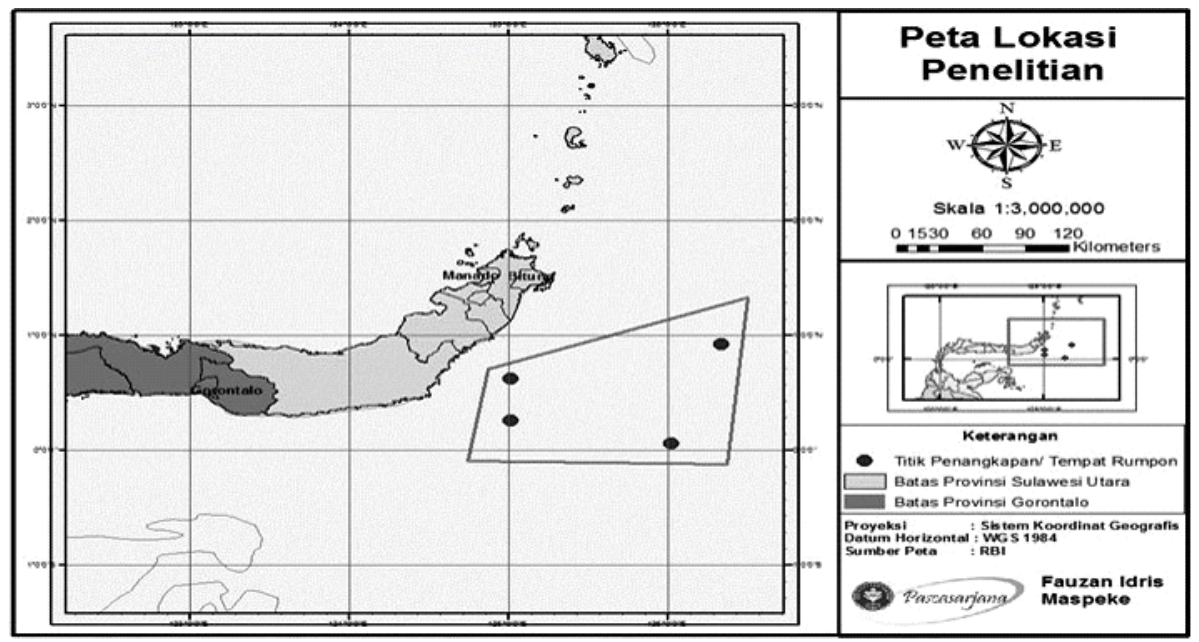

Gambar 1. Posisi daerah penangkapan ikan dimana huhate dioperasikan di sekitar rumpon. Figure 1. Fishing ground for pole and line operated around of FAD area.

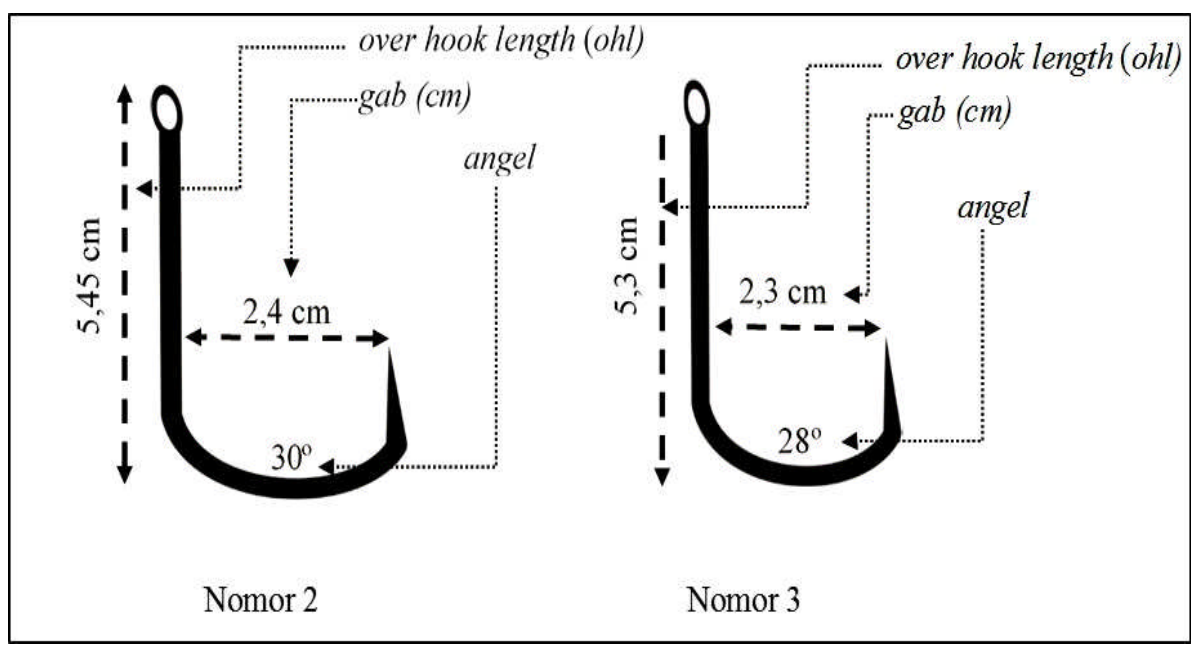

Gambar 2. Dimensi dan karakteristik mata pancing dengan ukuran berbeda (no 2 dan 3). Figure 2. Dimension and characteristicof hooks with different size (No. 2 and 3).

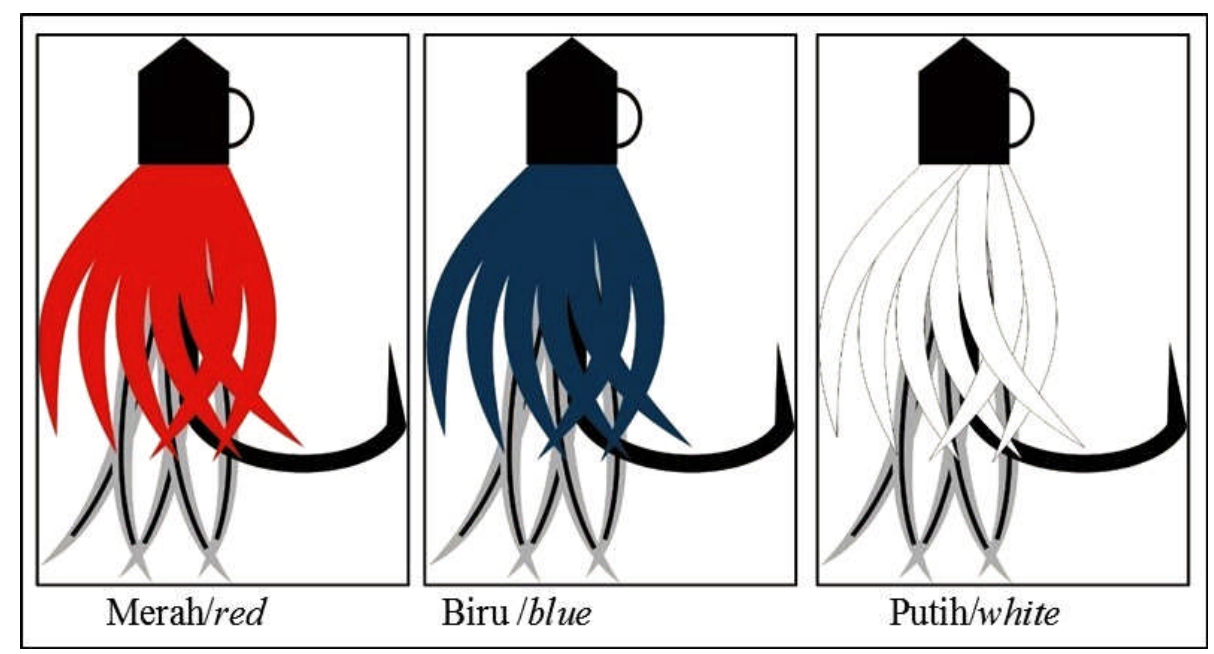

Gambar 3. Perpaduan ukuran mata pancing dengan warna umpan tiruan. Figure 3. Combination of hook size and artificial bait with different color. 
Tabel 1. Kombinasi perlakuan antara ukuran mata pancing dan warna umpan

Table 1. Combination of treatments between hooks size and artificial baits color

\begin{tabular}{ccc}
\hline Warna umpan tiruan & \multicolumn{2}{c}{ Ukuran mata pancing/Hook size } \\
\cline { 2 - 3 } Artificial bait color & Pancing No 3 & Pancing No 2 \\
\hline Merah/red & Kombinasi A & Kombinasi D \\
Biru/blue & Kombinasi B & Kombinasi E \\
Putih/white & Kombinasi C & Kombinasi F \\
\hline
\end{tabular}

Pengoperasian huhate dilakukan oleh 6 orang pemancing yang mana setiap pemancing harus memiliki pengalaman minimal 2 tahun. Dengan pemancing yang berpengalaman maka proses pengoperasian huhate dapat berjalan lancar tanpa ada ikan yang terlempar/terlepas kembali ke laut ketika ikan dinaikkan ke geladak kapal (Puspito, 2010). Ilustrasi posisi pemancing huhate berada di bagian depan kapal seperti disajikan pada Gambar 4.

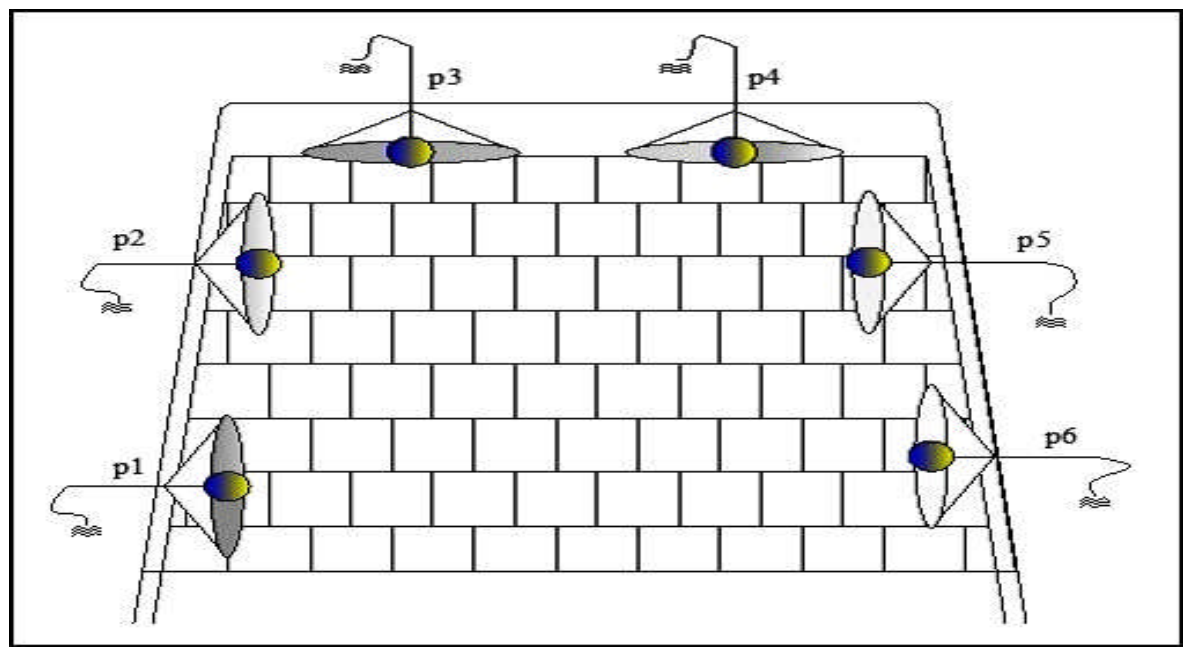

Gambar 4. llustrasi posisi masing-masing pemancing huhate (P1-P6) selama operasi penangkapan.

Figure 4. Illustration of each pole and line fisher position (P1-P6) during fishing operation.

Uji coba penangkapan dilakukan sebanyak 18 trip atau 72 hari di laut dengan 288 ulangan operasi penangkapan. Adapun ulangan dihitung berdasarkan jumlah operasi penangkapan (fishing operation). Sebanyak 4 operasi penangkapan dilakukan dalam sehari dan setiap perpindahan dari rumpon satu ke rumpon lainnya yang berjarak sekitar 5-10 mil dihitung sebagai 1 (satu) ulangan.

Tahapan pengoperasiannya diawali dengan perencanaan penangkapan dan pencarian umpan hidup. Selanjutnya, operasi penangkapan mengikuti urutan seperti berikut:

1. Setiap pemancing dibekali dengan 2 nomor ukuran mata pancing (No.2 dan 3) dan tiga warna umpan tiruan (merah, biru, dan putih). Pada hari pertama, pemancing 1 mengoperasikan mata pancing nomor 2 dan umpan warna merah, pemancing 2 (nomor 3; warna biru), pemancing 3 (nomor 2; warna putih), pemancing 4 (nomor 3 ; warna merah), pemancing 5 (nomor 2; warna biru) dan pemancing 6 (nomor 3; warna putih);
2. Kapal bergerak mendekati rumpon, kemudian pompa menyemprotkan air ke laut diopersikan, dan selanjutnya juru umpan melemparkan umpan ikan hidup (ikan teri) ke laut. Aktivitas pemancingan dilakukan setelah gerombolan ikan target mendekati kapal;

3. Ikan yang terpancing dilontarkan ke geladak kapal dan aktivitas penangkapan diulang kembali sampai gerombolan ikan dapat terpancing semua;

4. Ikan yang tertangkap oleh setiap pemancing diidentifikasi jenisnya kemudian diukur panjang dan beratnya, dan dicatat sesuai dengan kombinasi antara ukuran mata pancing dan warna umpannya.

Tahapan operasi penangkapan diulangi pada keesokan harinya. Pemancing menggunakan ukuran mata pancing dan warna umpan yang berbeda. Ukuran mata pancing dan warna umpan diusahakan tidak sama antara pemancing yang posisinya bersebelahan untuk menghindari terjadinya bias. 


\section{Analisa Data}

Analisis data hasil tangkapan huhate menggunakan dua metode analisis, yaitu secara deskriptif komparatif dan uji statistik. Analisis deskriptif komparatif dilakukan terhadap komposisi hasil tangkapan huhate (Walpole, 2007). Uji statistik menggunakan rancangan acak lengkap faktorial (RALF). Pengujian dilakukan pada 6 kombinasi mata pancing dengan warna umpan tiruan. RALF digunakan untuk melihat perbedaan hasil tangkapan (ekor) antar setiap kombinasi ukuran mata pancing dan warna umpan tiruan. Tabel 2 menyampaikan tabulasi data dan Tabel 3 merupakan sidik ragam yang digunakan dalam analisis statistik (Matjik \& Sumertajaya, 2006).

Persamaan umum RALF bertujuan untuk menilai hasil pengamatan pada kedua ukuran mata pancing (Fa) dan ketiga warna umpan tiruan (Fb) sehingga dapat diketahui pengaruh dari ukuran mata pancing dan warna umpan tiruan terhadap hasil tangkapan atau salah satu dari ukuran mata pancing dan warna umpan tiruan berpengaruh terhadap hasil tangkapan.

$$
\text { Yijk }=\mu+\alpha i+\beta j+(\alpha \beta) i j+\varepsilon i j k
$$

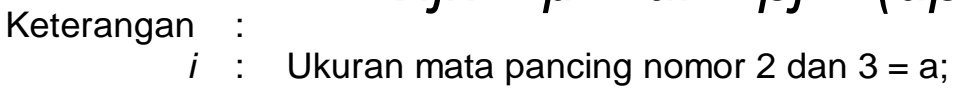

$j$ : Warna umpan tiruan merah, biru dan putih, = b;

Yijk : Nilai pengamatan pada faktor mata pancing dan warna umpan tiruan dengan ulangan $k$;

$k$ : Banyak ulangan: $1,2, \ldots, n$;

$\mu$ : Rataan umum;

ai : Koefisien faktor ukuran mata pancing (i);

$\beta j \quad$ Koefisien faktor warna umpan tiruan (j);

$(\alpha \beta) i j$ : Koefisien kombinasi faktor $i$ dan $k$ dan

eijk : Galat sisa;

Hipotesis

$\mathrm{Fa}: H_{0}: \alpha_{1}=\alpha_{2}=\ldots=\alpha_{i}=0$ : Perlakuan ukuran mata pancing tidak berpengaruh terhadap hasil tangkapan; dan

$H_{1}: \exists \alpha i \neq 0$ : Minimal ada satu perlakuan faktor ukuran mata pancing yang berpengaruh terhadap hasil tangkapan.

$\mathrm{Fb}: H_{0}: \beta_{1}=\beta_{2}=\ldots=\beta_{j}=0$ : Perlakuan warna umpan tiruan tidak berpengaruh terhadap hasil tangkapan; dan

$H_{1}: \exists \beta j \neq 0$ : Minimal ada satu perlakuan faktor warna umpan tiruan yang berpengaruh terhadap hasil tangkapan.

Fab : $H_{0}:(\alpha \beta)_{1}=(\alpha \beta)_{2}=\ldots=(\alpha \beta) i j=0$ : Perlakuan kombinasi faktor ukuran mata pancing (a) dan warna umpan tiruan (b) tidak berpengaruh terhadap hasil tangkapan; dan $H_{1}: \exists(\alpha \beta) i j \neq 0$ : Minimal ada satu perlakuan kombinasi faktor ukuran mata pancing (a) dan warna umpan tiruan (b) yang berpengaruh terhadap hasil tangkapan.

Tabel 2. Tabulasi data penelitian merupakan kombinasi ukuran mata pancing dan warna umpan Table 2. Data tabulation for the combination of hooks size and artificial baits color

\begin{tabular}{|c|c|c|c|}
\hline \multirow{2}{*}{ Warna Umpan Tiruan ( ()} & \multicolumn{2}{|c|}{ Ukuran Mata Pancing (I) } & \multirow[t]{2}{*}{ Total $(Y i)$} \\
\hline & Nomor 2 & Nomor 3 & \\
\hline \multirow[t]{3}{*}{ Merah/red } & k A1 & k D1 &.. \\
\hline & k A2 & k D2 & $\ldots$ \\
\hline & $\mathrm{k}$ An & $\mathrm{k}$ Dn & . \\
\hline \multirow[t]{2}{*}{ Biru/blue } & $\begin{array}{l}\text { k B1 } \\
\text { k B2 }\end{array}$ & $\begin{array}{l}\mathrm{kE1} \\
\mathrm{kE} \text { E }\end{array}$ & $\begin{array}{l}\ldots \\
\ldots\end{array}$ \\
\hline & k Bn & $k F n$ & $\cdots$ \\
\hline \multirow[t]{3}{*}{ Putih/white } & k C1 & k F1 & $\ldots$ \\
\hline & k C2 & k F2 & $\ldots$ \\
\hline & k Cn & k Fn & $\begin{array}{l}\cdots \\
\cdots\end{array}$ \\
\hline Total (Yj) & .. & $\ldots$ & Y... \\
\hline
\end{tabular}


Tabel 3. Sidik ragam dari analisis uji RALF

Table 3. Variance of RALF test analysis

\begin{tabular}{|c|c|c|c|c|c|}
\hline Sumber Keragaman & $\begin{array}{c}\text { Derajat Bebas } \\
(d B)\end{array}$ & $\begin{array}{c}\text { Jumlah } \\
\text { Kuadrat }(J K)\end{array}$ & $\begin{array}{c}\text { Kuadrat } \\
\text { Tengah } \\
(K T)\end{array}$ & $F_{\text {hitung }}$ & $F_{\text {tabel }}$ \\
\hline Kombinasi faktor & $i j-1$ & JKP & & & \\
\hline Warna umpan tiruan $(\mathrm{A})$ & $i-1$ & JKA & KTA & $F_{\text {hit }} \mathrm{A}$ & $F_{t a b} \mathrm{~A}$ \\
\hline Ukuran mata pancing (B) & $j-1$ & $\mathrm{JKB}$ & KTB & $F_{h i t} \mathrm{~B}$ & $F_{t a b} \mathrm{~B}$ \\
\hline & $(i-1)(j-1)$ & JKAB & KTAB & $F_{h i t} \mathrm{AB}$ & $F_{t a b} \mathrm{AE}$ \\
\hline Galat & $i j(n-1)$ & JKS & KTS & & \\
\hline Total & $\mathrm{AB} n-1$ & JKT & & & \\
\hline
\end{tabular}

Uji normalitas dan uji homogenitas dilakukan sebelum uji RALF diaplikasikan. Uji yang dipilih adalah uji normalitas Kolmogorov-Smirnov dan uji $\mathrm{F}$ (homogenitas). Kemudian, apabila hasil uji RALF menunjukkan perbedaan nyata, dilanjutkan dengan uji BNT (Beda Nyata Terkecil).

\section{HASIL DAN BAHASAN \\ Hasil}

\section{Komposisi Hasil Tangkapan}

Operasi penangkapan menggunakan huhate tertangkap empat jenis ikan pelagis besar, yaitu cakalang (Katsuwonus pelamis), juvenile tuna, madidihang (Thunnus albacares), dan tongkol (Auxis thazard). Jumlah tangkapan terbanyak adalah cakalang yang berjumlah 7.798 ekor atau $66 \%$ dari jumlah total hasil tangkapan dengan berat total mencapai $12.477 \mathrm{~kg}$. Juvenile tuna diurutan kedua dengan jumlah 331 ekor (18\%; berat $2.101 \mathrm{~kg}$ ), selanjutnya madidihang 168 ekor ( $9 \%$; berat 1.366 $\mathrm{kg}$ ), dan tongkol 802 ekor (7\%; berat $1.037 \mathrm{~kg})$. Keempatnya merupakan ikan pelagis yang tersebar secara luas di perairan tropis seperti di perairan Indonesia. Komposisi hasil tangkapan huhate berdasarkan jumlah tangkapan (ekor) disajikanpada Gambar 5. Adapun komposisi hasil tangkapan huhate berdasarkan berat tangkapan dijelaskan pada Gambar 6.

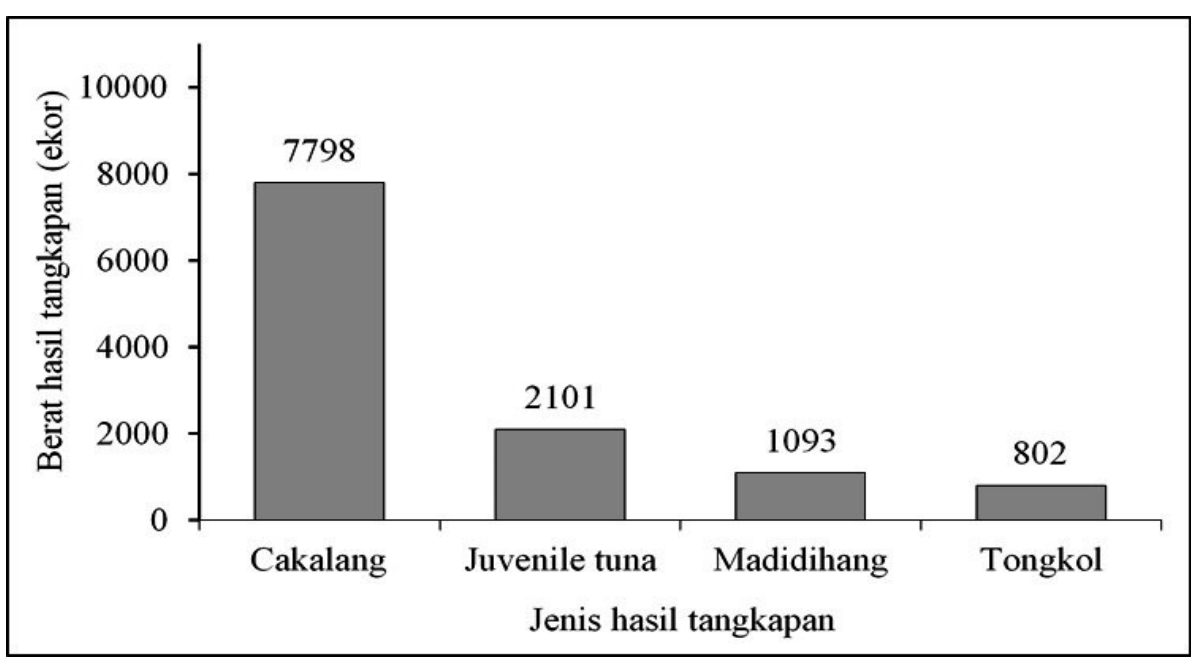

Gambar 5. Komposisi hasil tangkapan huhate berdasarkan jumlah tangkapan (ekor).

Figure 5. The catch composition caught by pole and line based on number of fish.

\section{Hasil Tangkapan Berdasarkan Ukuran Mata Pancing}

Hasil ujicoba huhate menunjukan bahwa ukuran mata pancing nomor 3 lebih banyak mendapatkan jumlah tangkapan dibandingkan ukuran nomor 2. Mata pancing nomor 3 jumlah tangkapannya sebanyak
7.105 ekor atau $60 \%$ dari seluruh jumlah hasil tangkapan. Sedangkan mata pancing bernomor 2 lebih sedikit jumlah tangkapan yaitu 4.689 ekor atau $40 \%$ dari seluruh jumlah hasil tangkapan. Jumlah hasil tangkapan berdasarkan ukuran mata pancing ditunjukan pada Gambar 7. 


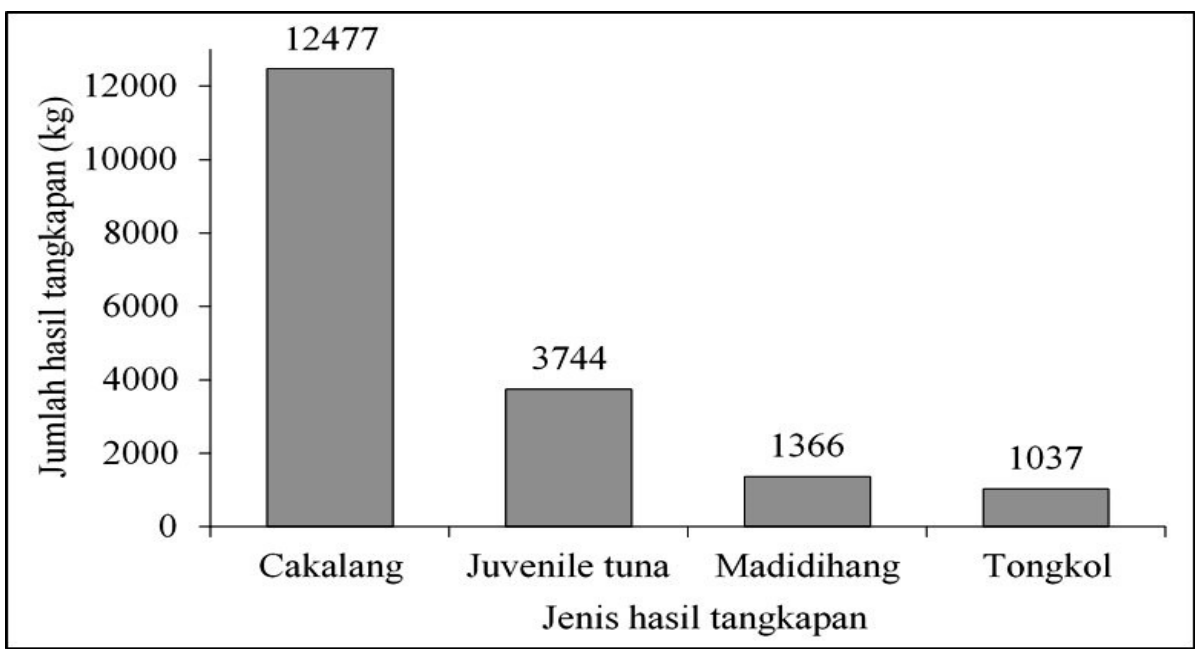

Gambar 6. Komposisi hasil tangkapan huhate berdasarkan berat hasil tangkapan.

Figure 6. Catch composition caught by pole and line based on weight of catch.

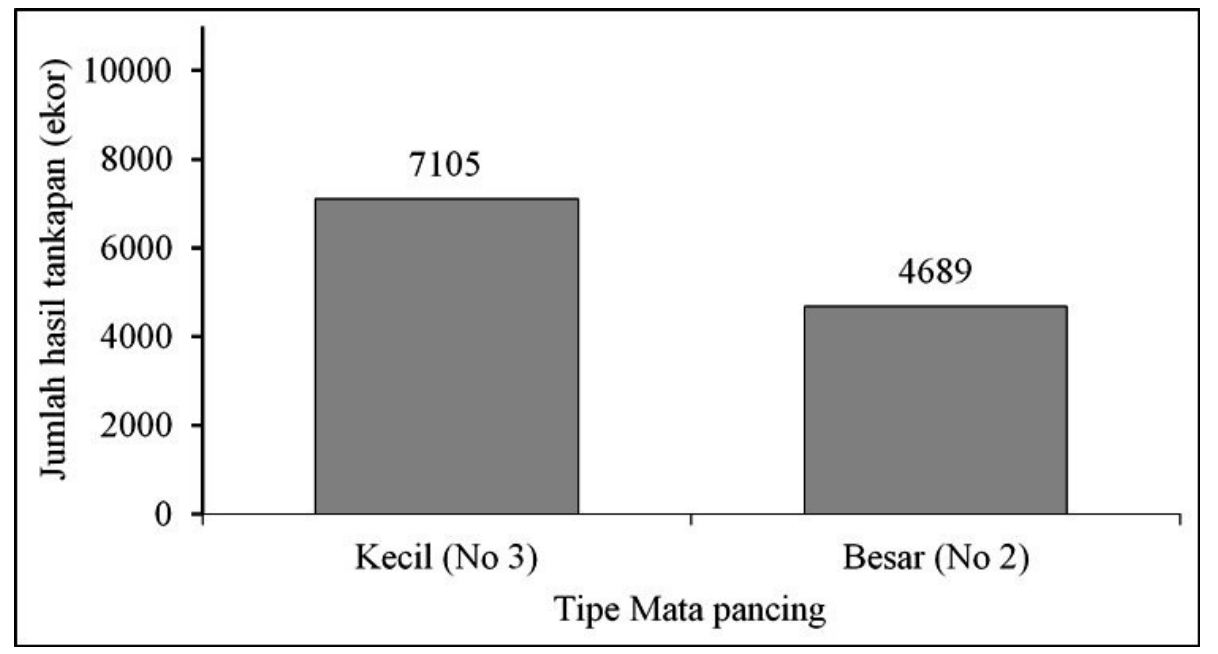

Gambar 7. Jumlah hasil tangkapan berdasarkan ukuran mata pancing.

Figure 7. Total catch in number of fish based on hook size.

Jumlah per jenis hasil tangkapan dapat dilihat berdasarkan ukuran mata pancing (Gambar 8). Jenisnya terdiri atas ikan cakalang, juvenile tuna, tuna sirip kuning/madidihang, dan tongkol. Mata pancing nomor 3 menangkap ikan cakalang sebanyak 4.698 ekor, juvenile tuna (1.266 ekor), tuna sirip kuning (658 ekor), dan tongkol (483 ekor). Sementara mata pancing nomor 2 menangkap ikan cakalang sebanyak 3.100 ekor, juvenile tuna (835 ekor), tuna sirip kuning (434 ekor), dan tongkol (319 ekor).

Uji statistik juga menunjukkan bahwa ada pengaruh ukuran mata pancing terhadap jumlah hasil tangkapan. Dari hasil uji RALF diketahui bahwa nilai $F_{\text {hit }}$ sebesar 118,809 dengan $F_{\text {tab }}$ sebesar $3,84\left(F_{\text {hit }}>F_{\text {tab }}\right)$.

\section{Hasil Tangkapan Berdasarkan Warna Umpan Tiruan}

Hasil uji coba huhate dengan ketiga warna umpan tiruan menghasilkan jumlah hasil tangkapan yang signifikan. Jumlah hasil tangkapan huhate menggunakan umpan tiruan berwarna merah menangkap sebanyak 4.702 ekor atau $40 \%$ dari total hasil tangkapan. Selanjutnya, warna biru menghasilkan sebanyak 3.733 ekor (32\%) dan warna putih 3.359 ekor (28\%). Jumlah hasil tangkapan berdasarkan warna umpan tiruan yang digunakan ditunjukkan pada Gambar 9. 


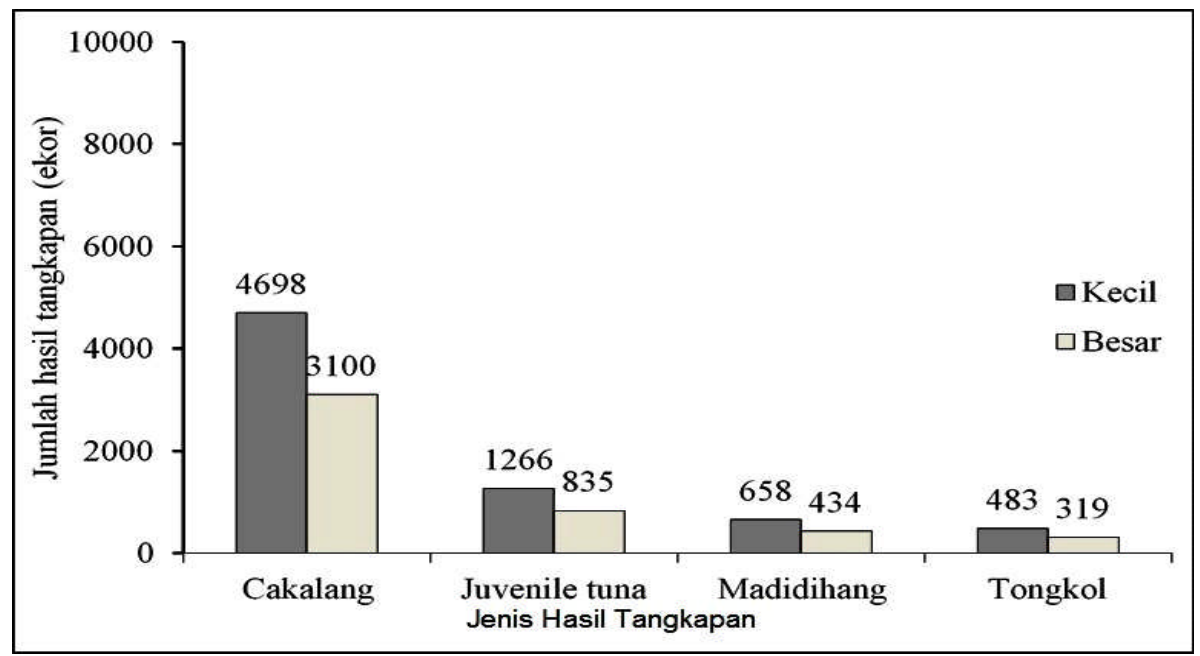

Gambar 8. Jumlah dan jenis hasil tangkapan berdasarkan ukuran mata pancing. Figure 8. Total catch in number of fish and species based on the hook size.

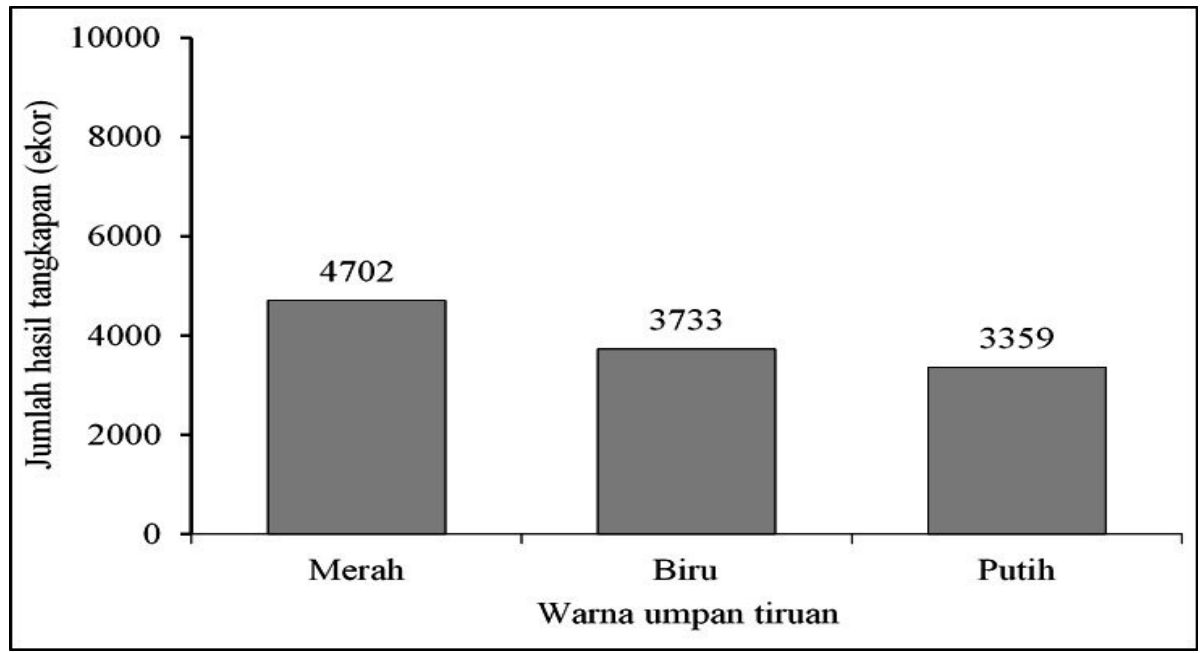

Gambar 9. Jumlah hasil tangkapan berdasarkan warna umpan tiruan.

Figure 9. Total catch in number of fish based on the color of the artificial bait.

Jumlah hasil tangkapan huhate berdasarkan warna umpan tiruan juga dapat dilihat berdasarkan jenis hasil tangkapan. Pada gambar 10, terlihat bahwa umpan tiruan warna merah tetap unggul dibandingkan umpan dengan warna lainnya untuk menangkap cakalang, juvenile tuna, tuna sirip kuning, dan tongkol. Cakalang tertangkap dengan umpan tiruan warna merah sebanyak 3.109 ekor, biru (2.468 ekor), dan putih (2.221 ekor). Kemudian, juvenile tuna tertangkap dengan umpan tiruan merah sebanyak 838 ekor, biru (665 ekor), dan putih (599 ekor). Tuna sirip kuning berada pada urutan ketiga. Jumlah yang tertangkap dengan umpan tiruan warna merah sebanyak 436 ekor, biru (346 ekor), dan putih (311 ekor). Sementara itu, tongkol berada pada urutan keempat dengan rincian jumlah yang tertangkap dengan umpan tiruan merah sebanyak 320 ekor, biru (254 ekor), dan putih (228 ekor).

\section{Hasil Tangkapan Berdasarkan Kombinasi Ukuran Mata Pancing dan Warna Umpan}

Jenis hasil tangkapan menyebar merata pada setiap kombinasi. Masing masing kombinasi menghasilkan tangkapan jenis ikan yang sama yaitu cakalang, juvenile tuna, madidihang/tuna sirip kuning, dan tongkol. Perbedaannya hanya pada jumlah dari hasil tangkapan.

Kombinasi ukuran mata pancing nomor 3 dan umpan tiruan warna merah (kombinasi A) memperoleh tangkapan terbanyak pada setiap jenis dan jumlah hasil tangkapan. Jenis dan jumlah ikan yang tertangkap terdiri atas cakalang sebanyak 1.808 ekor atau $70 \%$, juvenile tuna 432 ekor (17\%), madidihang 221 ekor (9\%) dan tongkol 136 ekor (5\%) dari jumlah seluruh hasil tangkapan. Urutan berikutnya adalah 
kombinasi B (nomor 3; warna biru) menangkap cakalang 1.587 ekor (66\%), juvenile tuna 466 ekor (19\%), madidihang 173 ekor (7\%) dan tongkol 173 ekor (7\%). Kemudian diikuti kombinasi C (nomor 3; warna putih) mendapatkan cakalang 1.538 ekor (73\%), juvenile tuna 361 ekor (17\%), madidihang 101 ekor (5\%) dan tongkol 109 ekor (5\%). Adapun kombinasi D (nomor 2; warna merah) memperoleh cakalang 1.367 ekor $(65 \%)$, juvenile tuna 329 ekor $(16 \%)$, madidihang 231 ekor (11\%) dan tongkol 179 ekor
(8\%). Selanjutnya, kombinasi E (nomor 2; warna biru) menangkap cakalang 789 ekor (59\%), juvenile tuna 257 ekor (19\%), madidihang 181 ekor (14\%) dan tongkol 109 ekor (8\%). Urutan terakhir kombinasi F (nomor 2; warna putih) menangkap cakalang 679 ekor (54\%), juvenile tuna 313 ekor (25\%), madidihang 163 ekor (13\%) dan tongkol 95 ekor (8\%). Jenis hasil tangkapan berdasarkan kombinasi mata pancing dan umpan tiruan secara rinci disampaikan pada Tabel 4.

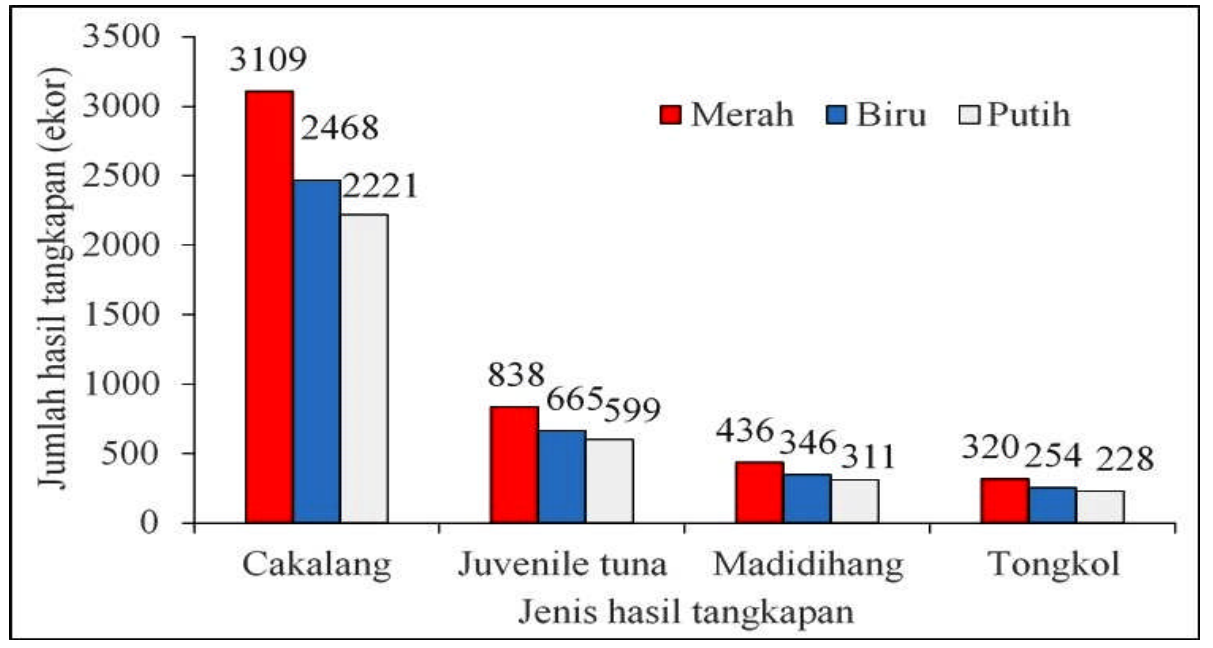

Gambar 10. Jumlah dan jenis hasil tangkapan huhate berdasarkan warna umpan tiruan.

Figure 10. Total number and species of fish caught by pole and line based on the color of the artificial bait.

Tabel 4. Komposisi jenis hasil tangkapan huhate berdasarkan kombinasi ukuran mata pancing dan warna umpan tiruan

Table 4. Catch composition of fish caught by pole and line using combination of hook size and artificial bait with different color

\begin{tabular}{|c|c|c|c|c|}
\hline \multirow{2}{*}{ Perlakuan } & \multicolumn{4}{|c|}{ Jumlah hasil tangkapan (ekor) } \\
\hline & Cakalang & Juvenile tuna & Madidihang & Tongkol \\
\hline Kombinasi $\mathrm{A}$ & 1716 & 463 & 241 & 176 \\
\hline Kombinasi B & 1587 & 428 & 222 & 163 \\
\hline Kombinasi C & 1394 & 376 & 195 & 143 \\
\hline Kombinasi D & 1392 & 375 & 195 & 143 \\
\hline Kombinasi $\mathrm{E}$ & 881 & 238 & 124 & 91 \\
\hline Kombinasi $\mathrm{F}$ & 826 & 223 & 116 & 85 \\
\hline Jumlah & 7798 & 2101 & 1093 & 802 \\
\hline
\end{tabular}

Perpaduan ukuran mata pancing dan warna umpan tiruan membentuk 6 kombinasi, yaitu kombinasi $A$ (nomor 3; merah), B (nomor 3; biru), C (nomor 3; putih), $\mathrm{D}$ (nomor 2; merah), $\mathrm{E}$ (nomor 2; biru), dan F (nomor 2; putih). Keenam kombinasi diuji coba secara bersamaan dengan kapal yang sama untuk mendapatkan kombinasi yang paling baik dalam mendapatkan hasil tangkapan ikan terbanyak.

Hasil uji coba penangkapan menunjukkan kombinasi A mendapatkan hasil tangkapan terbanyak, yaitu 2.596 ekor atau $22 \%$ dari total hasil tangkapan, diikuti kombinasi B: 2.400 ekor (20\%), kombinasi C: 2.109 ekor (18\%), dan kombinasi D: 2.106 ekor (18\%). Adapun kombinasi yang paling sedikit tangkapannya adalah kombinasi E dan $\mathrm{F}$ dengan jumlah tangkapan ikan masing-masing sebanyak 1.333 (11\%) dan 1.250 ekor (11\%). Jumlah hasil tangkapan ikan berdasarkan kombinasi mata pancing dan umpan tiruan ditunjukkan dengan Gambar 11. 


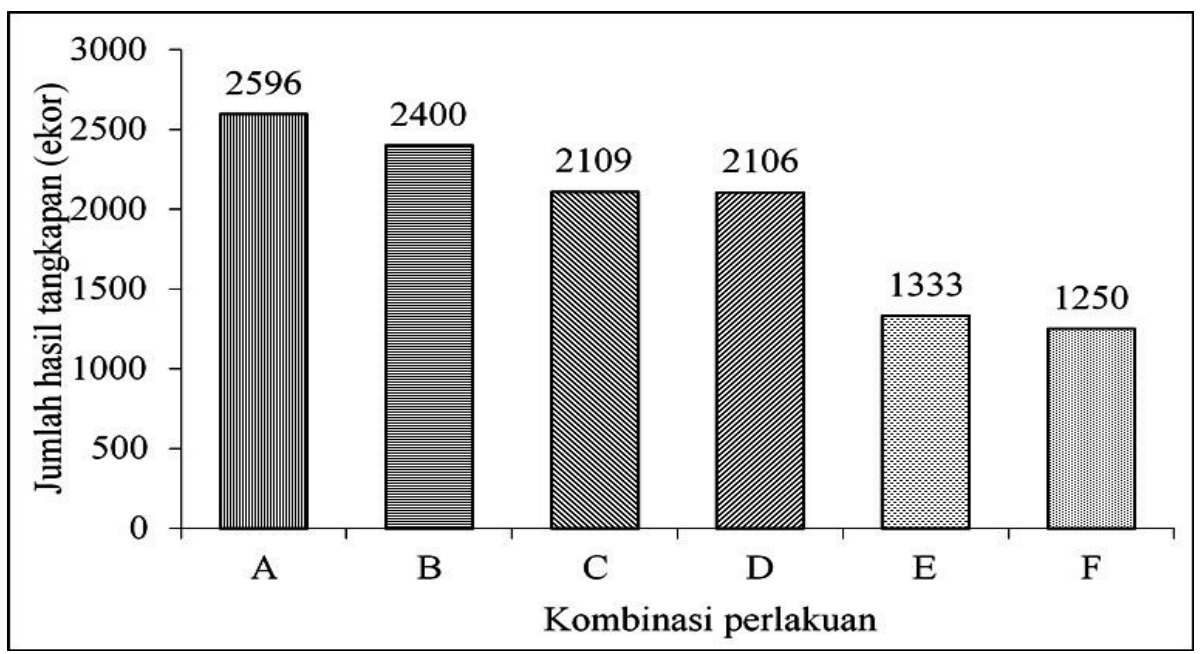

Gambar 11. Jumlah hasil tangkapan huhate dengan kombinasi perlakukan mata pancing dan warna umpan tiruan.

Figure 11. Number of fish caught by pole and line in combination treatment of hooks size and artificial bait color.

Uji statistik menunjukan bahwa kombinasi ukuran mata pancing dan warna umpan tiruan memiliki perbedaan nyata jumlah hasil tangkapan. Hasil uji RALF nilai F menghasilkan nilai F-hit sebesar 5,214 atau lebih besar daripada nilai F-tab $(3,027)$. Kemudian uji lanjutan (uji BNT) menghasilkan kombinasi A bernilai 52,97, kombinasi B $(48,97)$, kombinasi C $(43,04)$, kombinasi $D(42,97)$, dan kombinasi $\mathrm{E}$ dan $\mathrm{F}$ masing masing nilai 27,20 dan

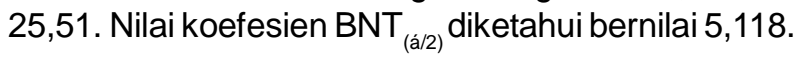

\section{Bahasan}

Cakalang adalah jenis ikan tangkapan dominan dari huhate yang jumlahnya mencapai 7.798 ekor $(12.477 \mathrm{~kg})$ atau $66 \%$ dari total hasil tangkapan. Jumlahnya sangat banyak dibandingkan dengan jumlah tangkapan ikan jenis lainnya. Jenis ikan cakalang hidup pada perairan lapisan atas (pelagis) dengan kedalaman 0-260 m dengan kisaran suhu rata-rata $15-30^{\circ} \mathrm{C}$ (Collette \& Naeun, 1983). Perairan Sulawesi Utara merupakan habitat dan jalur migrasi cakalang (Kekenusa, 2006). Pengoperasian huhate dilaksanakan pada periode September-November yang mana bulan tersebut bertepatan dengan musim penangkapan cakalang yaitu antara SeptemberDesember (Priyono et al., 1997).

Jumlah hasil tangkapan juvenile tuna (sulit dibedakan antara madidihang dan tuna mata besar) berada pada urutan kedua setelah ikan cakalang dengan jumlah 2.101 ekor $(3.744 \mathrm{~kg})$ atau $18 \%$ dari total hasil tangkapan. Hasil tangkapan juvenile tuna yang cukup tinggi berkaitan dengan jalur migrasi, tempat pemijahan, faktor rumpon, dan umpan yang digunakan. Sesuai dengan hasil penelitian Monintja (1993), bahwa perairan Laut Sulawesi merupakan daerah penangkapan ikan potensial untuk alat tangkap huhate, karena wilayah tersebut merupakan jalur migrasi dan tempat memijah tuna sehingga banyak ditemukan juvenile tuna yang tertangkap. Yusfiandayani et al. (2013) menambahkan bahwa rumpon dapat mempengaruhi keberhasilan penangkapan ikan menggunakan alat tangkap huhate, karena fungsinya sebagai pengumpul ikan. Selain itu, umpan hidup memberikan stimulus terhadap ikan mangsa untuk berkumpul dan mendekati lokasi penangkapan (Puspito 2010).

Madidihang/tuna sirip kuning berada pada urutan ketiga dari total jumlah hasil tangkapan huhate. Jenisnya masih tergolong ke dalam jenis ikan tuna daerah tropis. Jumlah hasil tangkapan ikan madidihang lebih sedikit dibandingkan jenis juvenile tuna, yaitu 10.933 ekor $(1.366 \mathrm{~kg})$ atau $9 \%$ dari total hasil tangkapan. Penyebabnya berhubungan dengan zona distribusi gerombolan ikan di suatu perairan (Okada,1955). Collette \& Naeun (1983) menyatakan bahwa madidihang menyukai kolom perairan yang mendekati zona termoklin atau perairan dalam. Tambunan (1964) menambahkan bahwa daerah penangkapan yang paling baik pada perairan bersuhu antara $14^{\circ} \mathrm{C}-27^{\circ} \mathrm{C}$ dengan suhu optimumnya antara $21^{\circ} \mathrm{C}-22^{\circ} \mathrm{C}$ pada kedalaman $100 \mathrm{~m}$.

Jenis ikan yang sedikit tertangkap oleh huhate adalah tongkol (neretic tuna). Terdapat berbegai jenis ikan tongkol yang tertangkap namun dikelompokan menjadi satu jenis. Jumlah tangkapnya hanya mencapai 802 ekor (1.037 kg) atau 7\% dari total hasil 
tangkapan. Tongkol tergolong sebagai ikan pelagis besar neritik, yaitu ikan pelagis yang tersebar di perairan pantai (Ghosh et al., 2012) pada hal sebagaian besar wilayah perairan Laut Sulawesi adalah tergolong perairan oseanik.

Perbedaan jumlah hasil tangkapan antar kombinasi menunjukkan adanya pengaruh kombinasi ukuran mata pancing dan warna umpan tiruan. Pembuktiannya juga ditunjukkan oleh hasil uji F. $F_{\text {hit }}$ bernilai 5,214 atau lebih besar daripada nilai $F_{\text {tab }}$ $(3,027)$. Rahaningmas et al. (2014) menjelaskan bahwa keberhasilan penangkapan menggunakan pancing tergantung pada 2 faktor penting, yaitu ukuran mata pancing dan warna umpan tiruan. Ukuran mata pancing berfungsi untuk menyesuaikan mata pancing dengan bukaan mulut ikan target. Kesesuaiannya mempengaruhi peluang tertangkapnya ikan sedangkan warna umpan tiruan berfungsi untuk meningkatkan daya tarik ikan terhadap umpan.

Kombinasi yang paling mempengaruhi jumlah hasil tangkapan dapat ditentukan berdasarkan uji statistik lanjutan yang digunakan (uji BNT). Hasil uji BNT menunjukkan kombinasi A dan $B$ adalah kombinasi yang paling efektif dibandingkan dengan kombinasi lainnya. Kombinasi $A$ unggul terhadap 4 dari 5 kombinasi lainnya. Jumlah hasil tangkapannya lebih banyak daripada kombinasi C, D, E, dan F, tetapi tidak terhadap kombinasi B. Meskipun jumlah hasil tangkapan kombinasi A lebih banyak, hasil uji BNT menunjukkan bahwa nilai kombinasi $A$ dan $B$ tidak berbeda nyata. Selisih rata-rata jumlah hasil tangkapan A dan B sebesar 4 atau lebih kecil dari pada $\mathrm{BNT}_{(a / 2)}(5,118)$. Kemudian, kombinasi $\mathrm{B}$ juga menghasilkan jumlah hasil tangkapan yang lebih banyak dibandingkan dengan kombinasi $C, D, E$, dan F. Dengan demikian, kombinasi A dan B memiliki kemampuan yang sama dalam menangkap ikan target (ikan tuna dan cakalang).

Kombinasi yang berada pada urutan 3 dan 4 adalah kombinasi $C$ dan D. Perbandingan jumlah hasil tangkapan dari kombinasi $C$ dan $D$ tidak berbeda nyata. Hasil uji BNT menunjukkan bahwa selisih ratarata jumlah hasil tangkapan $C$ dan $D$ sebesar 0,061 atau lebih kecil daripada $\mathrm{BNT}_{(\mathrm{a} / 2)}(5,118)$. Keduanya lebih unggul dibandingkan dengan kombinasi $\mathrm{E}$ dan F. Kombinasi yang menghasilkan jumlah hasil tangkapan paling sedikit adalah kombinasi $E$ dan $F$. Uji BNT menunjukkan perbandingan kombinasi $E$ dan $F$ tidak berbeda nyata berdasarkan jumlah hasil tangkapan. Selisih rata-rata jumlah hasil tangkapan $C$ dan $D$ sebesar 1,693 atau lebih kecil dibandingkan dengan nilai $\mathrm{BNT}_{(\text {(a) } 2)}(5,118)$.
Mata pancing merupakan salah satu faktor keberhasilan pengoperasian huhate. Menurut Nugraha et al. (2008), penggunaan ukuran mata pancing dapat disesuaikan dengan ukuran ikan hasil tangkapan. Oleh karena itu, penggunaan ukuran mata pancing disesuaikan dengan jenis ikan yang menjadi target penangkapan.

Berdasarkan hasil uji coba penggunaan ukuran mata pancing diketahui jumlah hasil tangkapan huhate menggunakan mata pancing nomor 3 lebih banyak dibandingkan dengan mata pancing nomor 2 . Mata pancing nomor 3 lebih efektif mendapatkan hasil tangkapan, karena lebih mudah menyesuaikan dengan dimensi mulut ikan target. Oleh karenanya, mata pancing nomor 3 memiliki peluang lebih besar untuk menangkap ikan dengan berbagai ukuran, mulai dari ukuran kecil hingga besar. Adapun mata pancing nomor 2 hanya memiliki peluang menangkap ikan dengan ukuran tertentu saja (Erzini et al., 1997; Puspito, 2010).

Cakalang mendominasi hasil tangkapan berdasarkan kedua tipe ukuran mata pancing. Jumlah totalnya mencapai 7.798 ekor atau $66 \%$ dari total hasil tangkapan. Diduga jumlah populasi ikan cakalang cukup melimpah di daerah penangkapan huhate, sehingga peluang tertangkapnya besar (Carpenter \& Niem, 2001). Selain itu, bukaan mulut cakalang juga mempengaruhi jumlah cakalang yang tertangkap (Young \& Davis 1990). Ukuran panjang tubuh dominan cakalang yang tertangkap berada pada selang kelas $38-40 \mathrm{~cm}, 41-43 \mathrm{~cm}$, dan $44-46 \mathrm{~cm}$. Ménard et al. (2006) menyatakan bahwa cakalang dengan ukuran panjang $<90 \mathrm{~cm}$ memiliki bukaan mulut untuk makanan berukuran $\pm 2,6 \mathrm{~cm}$. Ukuran ini sesuai dengan gap mata pancing yang digunakan, yaitu 2,3 $\mathrm{cm}$ dan $2,4 \mathrm{~cm}$.

Jenis ikan yang berada pada urutan kedua terbanyak tertangkap berdasarkan ukuran mata pancing adalah juvenile tuna. Jumlahnya mencapai 2.101 ekor. Juvenile tuna tertangkap oleh kedua tipe ukuran mata pancing, karena ukuran mata pancing sesuai dengan ukuran makanannya. Selang ukuran juvenile tuna yang tertangkap secara dominan berada pada rentang $35-37 \mathrm{~cm}, 38-40 \mathrm{~cm}, 41-43 \mathrm{~cm}$, dan 44$46 \mathrm{~cm}$. Ukuran ikan tuna yang $<90$ biasanya memakan makanan dengan ukuran $\pm 2,6 \mathrm{~cm}$. Jumlahnya tidak sebanyak hasil tangkapan cakalang, meskipun ukuran mata pancing sudah sesuai dengan kebiasaan makannya. Dua jenis hasil tangkapan yang tertangkap dengan jumlah sedikit berdasarkan ukuran mata pancing adalah tuna sirip kuning dan tongkol. Masingmasing memiliki jumlah total hasil tangkapan 
sebanyak 658 dan 483 ekor. Peluang tertangkap kedua jenis ikan sangat kecil, karena ukuran ikannya tidak sebesar cakalang dan juvenile tuna. Tuna sirip kuning didominasi oleh ikan berukuran panjang 3537 dan $38-40 \mathrm{~cm}$, sedangkan tongkol (38-40 dan 41$43 \mathrm{~cm}$ ). Panjang tubuh ikan yang memiliki hubungan dengan ukuran sangat mempengaruhi seleksi ukuran makanan ikan. Oleh karenanya, peluang kedua jenis ikan tertangkap dengan ukuran mata pancing yang digunakan cukup rendah (Menard et al., 2006; Young \& Davis, 1990).

Warna umpan memberikan stimulus terhadap pengoperasian huhate dimana fungsinya sebagai penarik perhatian ikan target penangkapan. Menurut Puspito (2010), penggunaan warna umpan tiruan sebaiknya berwarna terang saat didalam air agar mudah dikenali oleh ikan target. Ada 3 warna umpan tiruan yang digunakan oleh nelayan setempat, yaitu merah, biru dan putih.

Terdapat perbedaan hasil tangkapan berdasarkan warna umpan tiruan. Uji statistik juga menunjukkan hal yang sama. Berdasarkan uji F, nilai $F_{\text {hit }}>F_{\text {tab }}$, yaitu 5,214 (>3,027). Selanjutnya, uji BNT menunjukkan bahwa umpan tiruan merah lebih unggul dibandingkan umpan tiruan berwarna lainnya. Keunggulannya umpan denganwarna merah menyerupai warna satu makanan ikan target, yaitu ikan rambe (Encrasicholina devisi). Blaber et al. (1993) menyatakan bahwa ikan-ikan yang berasal dari famili Scombridae memangsa ikan rambe sebagai makanannya. Ikan target telah beradaptasi dengan warna makanannya, sehingga stimulus warna merah untuk memikat ikan target lebih tinggi dibandingkan dengan warna lain.

Umpan tiruan berwarna biru dan putih tidak berbeda nyata dalam menangkap hasil tangkapan. Jumlah hasil tangkapannya juga tidak lebih besar dibandingkan dengan warna merah. Penyebabnya adalah kekeruhan air yang dihasilkan dari rekayasa semprotan air dari kapal huhate. Puspito (2010) menyatakan bahwa buih yang dihasilkan oleh rekayasa hujan buatan/semprotan air dapat membuat umpan tiruan menjadi tidak tampak dan samar berakibat umpan tiruan biru dan putih mendapatkan hasil tangkapan lebih sedikit dibandingkan dengan umpan tiruan merah.

\section{KESIMPULAN}

Perpaduan antara ukuran mata pancing dan warna umpan tiruan yang terbaik jumlah tangkapannya adalah kombinasi A (mata pancing No. 3; umpan warna merah) sebanyak 2.596 ekor (22\%).
Selanjutnya diikuti oleh kombinasi B (No. 3; biru) 2.400 ekor, kombinasi C (No. 3; putih) 2.109 ekor, kombinasi D (No. 2; merah) 2.106 ekor, kombinasi E (No. 2; biru) 1.333 ekor, dan kombinasi F (No. 2; putih) 1.250 ekor. Dengan demikian, kombinasi paling baik digunakan pada huhate adalah kombinasi ukuran mata pancing bernomor 3 dan umpan tiruan berwarna merah sehingga dapat direkomendasikan untuk digunakan oleh nelayan.

\section{PERSATUNAN}

Penulis mengucapkan terima kasih kepada Saudara Sugeng Harianto, S.Pi dan teman teman Laboraorium Alat Penangkapan Ikan yang telah membantu dalam pengumpulan data. Ucapan terima kasih juga disampaikan kepada Saudara Keegan Kojoh, S.Pi (pemilik kapal) dan nelayan KM. Dioskuri 8 yang telah membantu dalam penyediaan kapal dan tenaga pemancing.

\section{DAFTAR PUSTAKA}

Blaber, S. J. M., Milton, D. A., Rawlinson, N. J. F., \& Sesewa, A. (1993). Predators of tuna baitfish and the effects of baitfishing on the subsistence reef fisheries of Fiji. In ACIAR PROCEEDINGS (pp. 5151). Australian Centre for International Agricultural Research.

Carpenter, K. E. \& Niem, V. H. (2001). FAO species identification guide for fishery purposes. The living marine resources of the Western Central Pacific. Volume 5. Bony fishes part 3 (Menidae to Pomacentridae). FAO species identification guide for fishery purposes. The living marine resources of the Western Central Pacific. Volume 5.

Collette, B. B. \& Aadland, C. R. (1996). Revision of the frigate tunas (Scombridae, Auxis), with descriptions of two new subspecies from the eastern Pacific. Fish. Bull, 94(3), 423-441.

Collette B B. C E Nauen. (1983). FAO Species Catalogue. Scombrids of the world. An annotated and illustrated catalogue of tunas, mackerels, bonitos and related species known to date. Rome: FAO. FAO Fish. Synop. 125(2):137

Erzini, K., Gonçalves, J. M., Bentes, L., \& Lino, P. G. (1997). Fish mouth dimensions and size selectivity in a Portuguese longline fishery. Journal of applied Ichthyology, 13(1), 41-44.

Kekenusa, J. S. (2006). Analisis penentuan musim penangkapan ikan cakalang (Katsuwonus pelamis) 
di perairan sekitar Bitung Sulawesi Utara. JP. 13(1), 103-109.

Matjik, A. S. \& Sumertajaya, M. (2006). Perancangan percobaan (dengan Aplikasi SAS dan Minitab). Bogor (ID): IPB Pr. p. 98-178.

Ménard, F., Labrune, C., Shin, Y. J., Asine, A. S., \& Bard, F. X. (2006). Opportunistic predation in tuna: a size-based approach. Marine Ecology Progress Series, 323, 223-231.

Monintja, R. D. (1993). Study on the development of rumpon as fish aggregation device in Indonesia. Buletin ITK, Maritek, 3(2), 132.

Niam, A., Fitri, A. D. P., \& Yulianto, T. (2013). Perbedaan warna umpan tiruan terhadap hasil tangkapan ikan tongkol (Euthynnus affinis) pada alat tangkap pancing tonda di perairan Karimunjawa Jepara. Journal of Fisheries Resources Utilization Management and Technology. 2(3), 202-212.

Nugraha, B., \& Rahmat, E. (2008). Status perikanan huhate (pole and line) di Bitung, Sulawesi Utara. Jurnal Penelitian Perikanan Indonesia, 14(3), 311-318. doi: http://dx.doi.org/10.15578/ jppi.14.3.2008.313-320.x

Priyono, B. E., Widodo, J., Aziz, K. A., Mertha, G. S., Djamali, A., \& Tampubolon, G. H. (1997). Potensi dan penyebaran sumberdaya ikan laut di Perairan Indonesia. Direktorat Jenderal PerikananDepartemen Pertanian. Jakarta. p. 33-53.

Puspito, G. (2010). Warna umpan tiruan pada huhate. Jurnal Saintek Perikanan. 6(1), 1-7.

Rahaningmas, J. M., Puspito, G., \& Wahju, R. I. (2014). Hairtails fishing (Trichiurus sp.) effectiveness using artificial bait. Jurnal Teknologi Perikanan dan Kelautan, 5(1), 33-40.
Siswoko, P., Pramono, W., \& Fitri, A. D. P. (2013). Pengaruh perbedaan jenis umpan dan mata pancing terhadap hasil tangkapan pada pancing coping (hand line) di daerah berumpon perairan Pacitan Jawa Timur. Journal of Fisheries Resources Utilization Management and Technology. 2(1), 66-75.

Susanto, E., Boesono, H., \& Fitri, A. (2012). Pengaruh perbedaan penggunaan umpan terhadap hasil tangkapan ikan cakalang (Katsuwonus Pelamis) pada alat tangkap huhate di perairan Ternate Maluku Utara. Journal of Fisheries Resources Utilization Management And Technology.Volume 1 (1):138-147.

Tambunan, D. M. D. (1964). Penangkapan Ikan Tuna Dengan Long Line. Skripsi dalam mata ajaran teknik penangkapan.Fakultas Perikanan IPB.

Walpole, Ronald, E., Myers., Raymond, H., Sharon, L., \& Keying, Y. (1990). Probability and Statistics for Engineers and Scientists. Upper Saddle River, NJ: Pearson: 816.

Young, J. W., \& Davis, T. L. (1990). Feeding ecology of larvae of southern bluefin, albacore and skipjack tunas (Pisces: Scombridae) in the eastern Indian Ocean. Marine Ecology Progress Series, 17-29.

Yusfiandayani, R., Jaya, I., \& Baskoro, M. S. (2013). Uji coba penangkapan pada rumpon portable di perairan Palabuhanratu. Jurnal Teknologi Perikanan dan Kelautan, 4(1), 89-98. 